
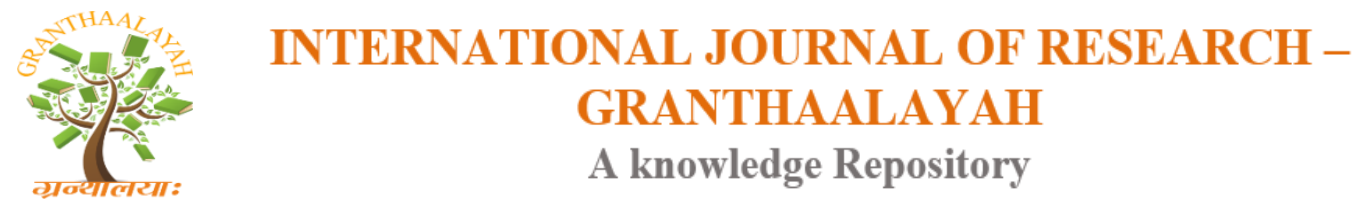

DOI: 10.5281/zenodo.1194665

Science

\title{
BASIC CHARACTERISTICS OF THE PLUVIOMETRIC REGIME IN THE UNA RIVER BASIN
}

\author{
Korjenić Aida ${ }^{1}$, Temimović Emir ${ }^{2}$, Banda Amra ${ }^{3}$, Sivac Amina ${ }^{4}$ \\ 1, 2, 3,4 Department of Geography, Faculty of Science, University of Sarajevo, Sarajevo, Bosnia \\ and Herzegovina
}

\begin{abstract}
Intensity of action and frequency of high and low pressure barometric fields of large and medium scale have great influence on dynamics of pluviometric regime. On their action depend characteristics of thermic regime, relative humidity, cloudiness and windiness, which directly affect the precipitation. Concerning that the water balance is difference between the inflow and evaporation, it comes that precipitations do not have just special role, but they are also the most important factor of the Una river regime. Disposition and precipitation structure are the river regime's essential assumptions, so at the same annual height of precipitation, we have more water in rivers in the year with more precipitations during the colder period. Then we have less evaporation so the inflow from the basin is bigger.

The amount and disposition of the precipitation in the Una River basin is analyzed in this paper in order to define the pluviometric regime of this area. Pluviometric regime greatly influences the Una river regime and water balance, what was the reason for this analysis and further hydrological research in the Una River basin.
\end{abstract}

Keywords: The Una River Basin; Precipitations; Pluviometric Regime.

Cite This Article: Korjenić Aida, Temimović Emir, Banda Amra, and Sivac Amina. (2018). "BASIC CHARACTERISTICS OF THE PLUVIOMETRIC REGIME IN THE UNA RIVER BASIN." International Journal of Research - Granthaalayah, 6(2), 234-245. https://doi.org/10.5281/zenodo.1194665.

\section{Introduction}

The Una River basin feeds the Sava River with water, and it is a part of the Black Sea Basin. The Una basin, located in the northwest of Bosnia and Herzegovina, partly crosses into the neighboring Croatia. It borders with the following basins: the Vrbas and the Pliva on the east and southeast, the Cetina, Krka and Zrmanja on the south and southwest, underground waters on the west flow towards Gacko polje, while with basins of the Korana and Glina it borders on the northwest and with direct Sava basin on the north. Various data on the area covered by the Una basin can be found in the professional papers. The data are mainly stated that the basin covers in total $9640 \mathrm{~km}^{2}$ (Spahić, 1991), on the territory of Bosnia and Herzegovina $9368 \mathrm{~km}^{2}$, of which 
on the territory of Federation of Bosnia and Herzegovina $5020 \mathrm{~km}^{2}$ (Žigić, et al., 2010). Majority of data is linked to orographic, relatively topographic watershed which, due to prevail terrains with aquifers of fracture-cavernous porosity, does not make a real watershed between neighboring basins and the Una basin, so it should be taken with the reserve. It is very hard to determine the concrete and accurate watershed, so as the basin surface, until directly hydrogeological researches are done in the whole basin's area (Spahić, Korjenić, Hrelja, 2014).

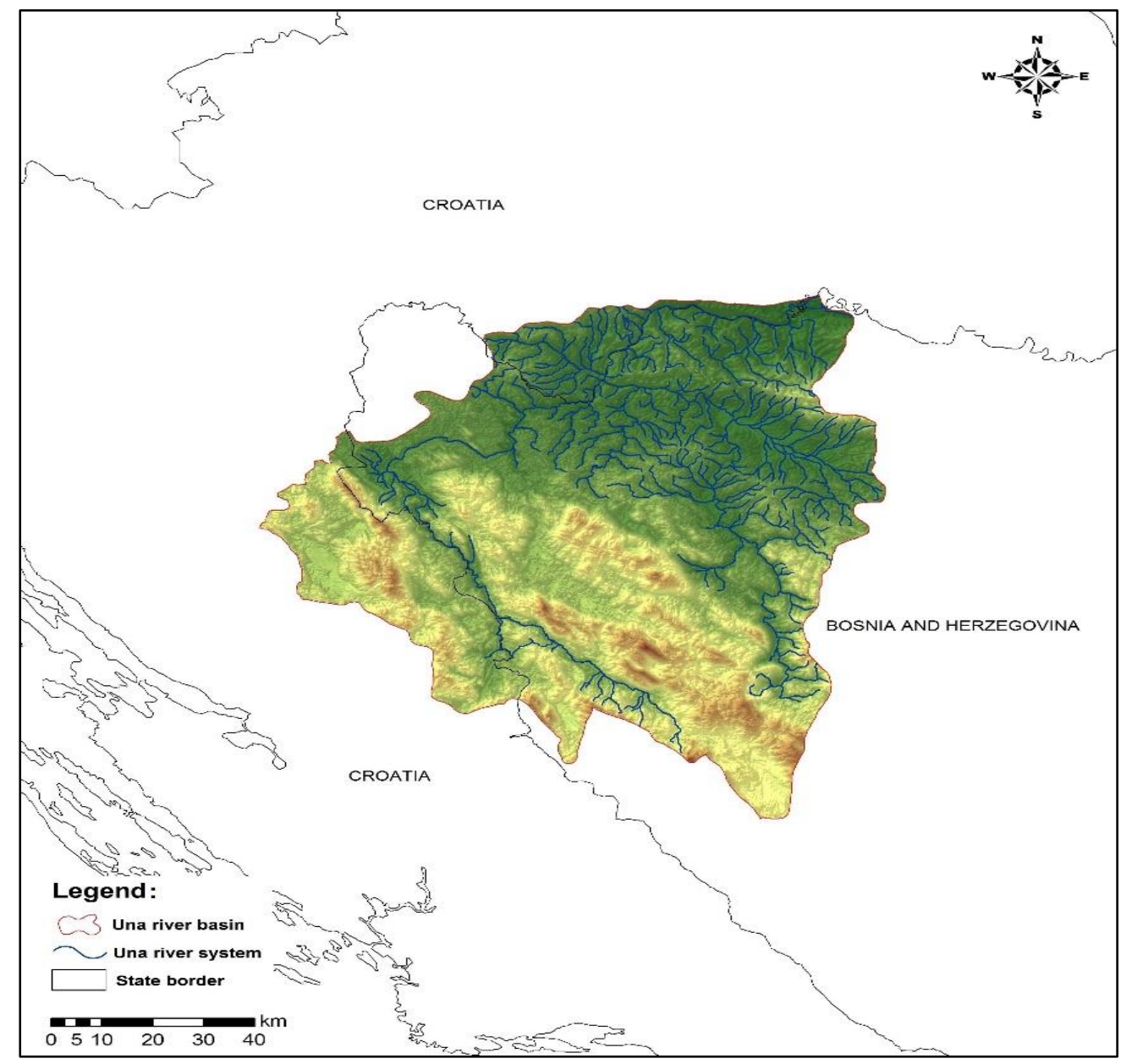

Figure 1: Geographical position of the Una River basin

Recently, such researches were conducted in the area of the western and southwest part of the watershed. Since there were no large-scale hydrogeological charts for this area, as a basis for this paper, hydrogeological chart of the former Yugoslavia was used, Zagreb, Sarajevo and Dubrovnik papers with scale 1:500 000, with certain changes due to recent research [8]. Based on the mentioned map and supplement, the Una basin was segregated (according to the own measurements from charts in the program ArcGIS 9, ArcMap) with surface area of $9979.5 \mathrm{~km}^{2}$. General climate characteristics in the Una River basin are consequences of physical-geographic determinants and predominantly zonal and azonal position of this area. In zonal view, the Una River basin's area is situated inside two large climate belt zone that are: the southern parts of the northern moderate belt and the northern parts of the northern hemisphere subtropical belt. The southern parts of the basin approached the Adriatic facade, from that reason significant 
subtropical influence is felt on this area. Longitudinal, the basin belongs to the western pre-ocean Atlantic Ocean sector. The Una basin is broadly open to the continental climate effects coming from the north and northeast. The Una and the Sana valleys contribute to this, with their predominantly meridional stretch direction, by which the influences of continental air spread deep into the interior of mountain-valley space. Above the analyzed area, western circulation moisture rich air masses (maritime polar and maritime tropical) change with mainly dry air masses from the continental east, northeast and north (continental arctic and continental polar) and sub-tropical masses from the African north (continental tropical). Climate conditions and weather conditions are affected, to a large degree, also by geographic distribution of cyclogenetic areas and frequency passages of fronts, cyclones and anticyclones. For the wider area in which the Una basin is situated, characterized are also significant influences of winter Atlantic cyclone, summer Azores anticyclones, and during a year, Siberian anticyclones.

Considering the global distribution of air masses, belts (zones) and sectors, it can be distinguished zonal layout of isotherms and monthly isotherms, but also isohyets in the Una basin area. However, hypsometric position and exposition to the general global air circulation brought to uneven precipitation and temperature disposition in certain areas inside these zones. The analysis on climatic elements and appearances led to the conclusion that a moderately continental type or a moderately warm and a humid climate type $(\mathrm{Cfb})$, that is beech climate, were formed in this area in lower hypsometric levels and generally in the basin's larger part.

\section{Materials and Methods}

For the analysis of pluviometric regime it is necessary to know disposition and amount of the precipitation in the basin. Precipitation quantitative value determination in the basin was difficult also due to a relatively small number of observation stations, which, almost as a rule, did not have complete sets of observations. Because of that reason, for determination of precipitations falling on a basin's surface, three different methods were used in this paper. Based on finding the weight coefficient for precipitation measured at a given point, those are: arithmetic mean method, the Thiessen polygon method and isohyet method.

The arithmetic mean method is used mainly at basins which do not have a pronounced vertical separation of the relief, nor do they have greater differences in precipitation amount. Thus, this method gives a rough estimation of the average precipitation value. According to Hrelja $\mathrm{H}$. (2007), if it is assumed that every pluviometer on, or in the vicinity of the analyzed basin has equal weight $\mathrm{w}_{\mathrm{i}}=1 / \mathrm{n}$, where $n$ - number of pluviometers taken into consideration, then the definition term for the average precipitation quantity in the basin is:

$\bar{P}=\sum_{i=1}^{n} P i w i=\frac{1}{n} \sum_{i=1}^{n} P i=\frac{P 1+P 2+\cdots+P n}{n}$

In this case $\mathrm{P} 1, \mathrm{P} 2, \ldots, \mathrm{Pn}$ are precipitation heights taken from the pluviometer monitoring in the basin.

Applying the Thiessen polygon method, all meteorological monitoring in and around the basin have come into consideration with the assumption of linear change in precipitation heights between the two observation points. In order to determine polygonal surface on the basin, it is 
necessary to connect all measuring stations to make up a network of triangles. The symmetries of all sides of the triangle are the sides of the polygon for individual meteorological stations (Hrelja, 2007). Thus, the Thiessen's procedure is based on the basin division on areas for which the data of each meteorological station on and around the basin are approximately valid. Although this method is also the most suitable for flatland basins without more expressive change of topographic and meteorological factors and at uneven distribution of pluviometer monitoring spaceward, yet it is the most commonly used method in hydrological practice. According to this method, the average precipitation amount $\mathrm{P}$, which is excreted on the basin surface is determined by the term:

$\mathrm{P}=\frac{F 1 P 1+F 2 P 2+\cdots+F n P n}{(F 1+F 2+\cdots+F n)}$

Where:

$\mathrm{P}$ - Annual precipitation amount in the basin area in $\mathrm{mm}$;

Fn - surface of polygons that belong to individual monitoring points;

$\mathrm{Pn}$ - precipitation height.

The isohyet method is based on an average precipitation amount between the two isohyets multiplied with surface between them (Ducić, Anđelković, 2004). It is calculated for all isohyets on the basin surface, and a sum of obtained multipliers gives the average precipitation amount in the basin.

During the work, the following mathematical forms were used to get information about:

Relative annual precipitation fluctuations [9], $\mathrm{R}=\frac{H x-H n}{H} * 100 \quad(\%)$

Where: $\mathrm{Hx}$ - the highest monthly precipitation height, $\mathrm{Hn}$ - the lowest monthly precipitation height and $\mathrm{H}$ - annual precipitation height;

continentality [9], $\mathrm{Q}=\frac{R(I I I-I X)}{R(I-X I I)} * 100(\%)$

\section{Results And Discussions}

\subsection{Precipitation in the Una Basin}

Spatial coverage of the Una basin, considering its position and size, gets also various precipitation amounts. From the data from Table 1, an increase in annual precipitation amount is observed along with increase in the altitude of the station, which however is not continuous, and there are exceptions. The reason for this fact comes from the position of individual meteorological stations, relief characteristics, but also from atmospheric processes.

Table 1: The annual precipitation flow in the Una basin in the period 1961-1990 (mm)

\begin{tabular}{|l|l|l|l|l|l|l|l|l|l|l|l|l|l|l|}
\hline & H(m) & I & II & III & IV & V & VI & VII & VIII & IX & X & XI & XII & $\sum$ \\
\hline Bihać & 246 & 86 & 91 & 99 & 115 & 116 & 109 & 107 & 109 & 108 & 109 & 146 & 111 & 1308 \\
\hline Drvar & 485 & 77 & 82 & 83 & 89 & 95 & 98 & 73 & 90 & 98 & 90 & 128 & 105 & 1108 \\
\hline $\begin{array}{l}\text { Bosanska } \\
\text { Krupa }\end{array}$ & 176 & 73 & 78 & 89 & 109 & 109 & 120 & 100 & 107 & 92 & 99 & 119 & 98 & 1192 \\
\hline $\begin{array}{l}\text { Bosanski } \\
\text { Petrovac }\end{array}$ & 669 & 79 & 86 & 89 & 97 & 109 & 98 & 82 & 91 & 86 & 94 & 126 & 112 & 1149 \\
\hline
\end{tabular}




\begin{tabular}{|l|l|l|l|l|l|l|l|l|l|l|l|l|l|l|}
\hline Cazin & 376 & 76 & 76 & 82 & 102 & 104 & 115 & 93 & 95 & 96 & 88 & 129 & 96 & 1152 \\
\hline Drinić & 730 & 94 & 97 & 110 & 118 & 117 & 114 & 95 & 96 & 103 & 108 & 146 & 133 & 1331 \\
\hline $\begin{array}{l}\text { Kulen } \\
\text { Vakuf }\end{array}$ & 348 & 88 & 88 & 81 & 92 & 113 & 89 & 69 & 96 & 88 & 103 & 138 & 107 & 1151 \\
\hline $\begin{array}{l}\text { Bosanska } \\
\text { Kostajnica }\end{array}$ & 112 & 76 & 60 & 72 & 91 & 79 & 103 & 94 & 92 & 69 & 97 & 85 & 84 & 1004 \\
\hline $\begin{array}{l}\text { Bosanski } \\
\text { Novi }\end{array}$ & 119 & 70 & 66 & 77 & 85 & 98 & 96 & 87 & 86 & 82 & 82 & 104 & 86 & 1020 \\
\hline Sanski Most & 158 & 68 & 62 & 79 & 88 & 96 & 104 & 96 & 93 & 80 & 80 & 94 & 84 & 1023 \\
\hline Ključ & 272 & 69 & 69 & 79 & 100 & 100 & 116 & 97 & 87 & 93 & 83 & 99 & 90 & 1080 \\
\hline Prijedor & 135 & 65 & 55 & 68 & 80 & 85 & 89 & 89 & 82 & 77 & 74 & 88 & 76 & 927 \\
\hline Saničani & 141 & 73 & 55 & 68 & 78 & 82 & 89 & 83 & 84 & 82 & 75 & 82 & 79 & 930 \\
\hline $\begin{array}{l}\text { Lušci } \\
\text { Palanka }\end{array}$ & 431 & 83 & 83 & 99 & 124 & 122 & 129 & 122 & 116 & 111 & 106 & 131 & 113 & 1338 \\
\hline $\begin{array}{l}\text { Bosanska } \\
\text { Dubica* }\end{array}$ & 100 & 64 & 60 & 58 & 79 & 89 & 106 & 86 & 80 & 68 & 67 & 94 & 95 & 946 \\
\hline $\begin{array}{l}\text { Bosansko } \\
\text { Grahovo* }\end{array}$ & 861 & 126 & 122 & 102 & 96 & 106 & 109 & 80 & 78 & 89 & 123 & 125 & 191 & 1347 \\
\hline Glamoč* & 1031 & 136 & 114 & 100 & 122 & 113 & 103 & 74 & 91 & 97 & 140 & 206 & 201 & 1497 \\
\hline Una Basin & & 83 & 79 & 84 & 98 & 102 & 105 & 90 & 93 & 89 & 95 & 120 & 109 & 1147 \\
\hline
\end{tabular}

Source: According data HMZ FB\&H, Sarajevo 2013.

*20th year period

Relation between precipitation and altitude can be established also on the base of linear correlation. The analysis showed that the annual precipitation amount in the Una basin increases by $47.7 \mathrm{~mm}$ per every $100 \mathrm{~m}$. According to Drešković N. (2011), the average for Bosnia and Herzegovina amounts $23.0 \mathrm{~mm} / 100 \mathrm{~m}$, so the obtained value for the Una basin is twice larger.

Although the precipitation increases with altitude, during the work a conclusion has been reached that the precipitation increase along with altitude is not uniform and even. The position of meteorological station dominantly affects these precipitation relationships, as well as cyclonic activities or degree of the area continentality where the measurement of this climatic element is performed.

In order to try to show the relationships between annual precipitation amounts with altitude more faithfully, it has been analyzed linear correlation of meteorological monitoring data by hypsometric zones. The largest number of stations is located within the hypsometric zone of up to $200 \mathrm{~m}$. Within them there are evident differences when it comes to the annual precipitation amount. Concerning the small altitude difference and large oscillations of precipitation amounts on individual monitoring within the zone, linear correlation is extremely large and it comes from the relation: $\mathrm{P}=2.2293 \mathrm{xh}+706.31$.

Negative linear trend appears within the zone of 200 up to $500 \mathrm{~m}$, due to a large precipitation amount occurrence in Bihać and Lušci Palanka, which affects normal and homogenized precipitation increase with altitude. Extremely large precipitation amount registered in this area can be explained by their excretion in warmer part of a year, due to vertical thermic convection from cumulonimbus clouds. Larger areas of valleys and fields at lower altitudes will receive larger precipitation amount comparing to the surrounding, hypsometrically higher zones in which 
comes to cumulonimbus cloud degradation and by that also to the cessation of precipitation. Linear trend established in this zone amounts $\mathrm{P}=-0.0408 \mathrm{xh}+1204$.

The zone above $500 \mathrm{~m}$ altitude is characterized by homogenized increase with altitude, though the largest changes are seen at the altitude of 600 up to $700 \mathrm{~m}$. On the base of conducted linear correlation, the following indicator was obtained: $\mathrm{P}=0.8195 \mathrm{xh}+656.73$.

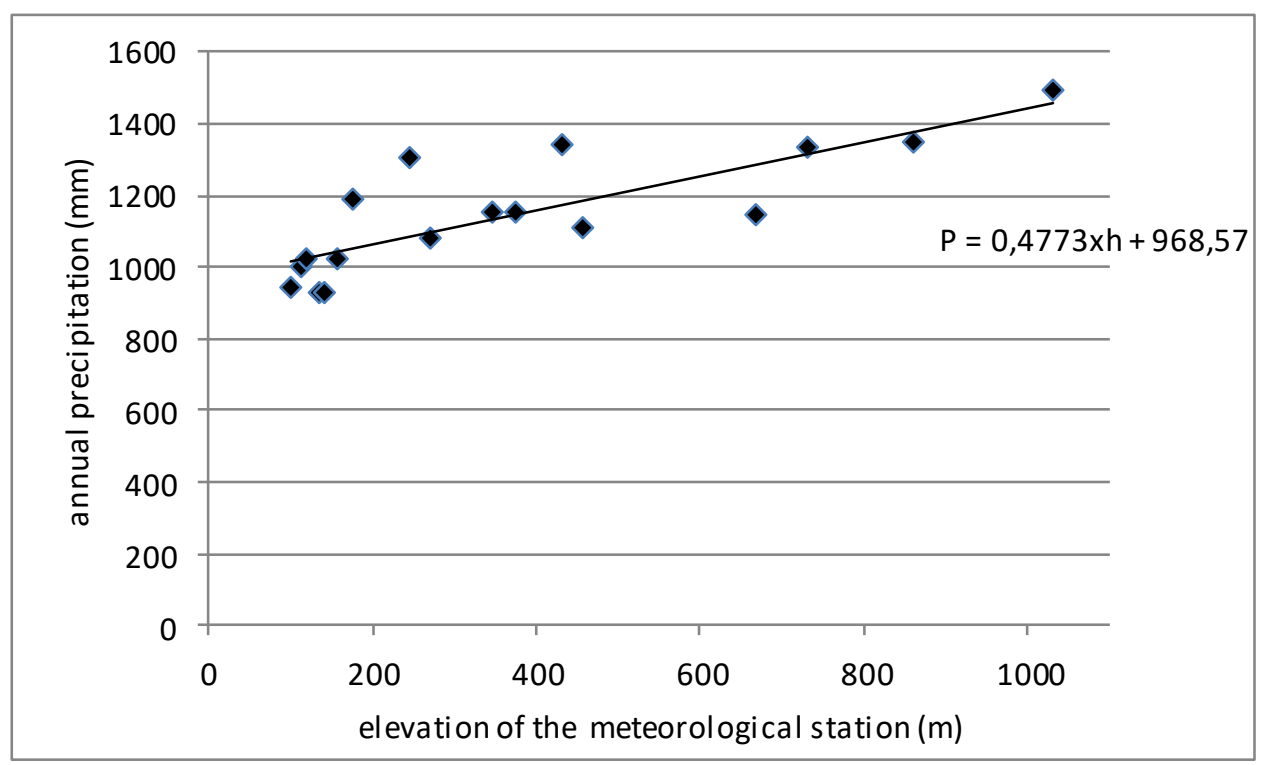

Figure 2: The regression direction graph (relationship between the altitude and precipitation) in the Una Basin

The rate of the annual precipitation increases along with altitude, for the Una basin as a whole, we should take with reserve, because the allocation of meteorological stations all over the basin is unequable on horizontal and vertical profile. The same rates of precipitation growth with altitude cannot be expected in all parts of the basin also due to the relief dynamics. Besides, precipitation measurements at the meteorological stations as individual points, does not bring enough information on precipitation falls on the basin area that, in fact, represents the basic interest for the water flow process.

There are a number of different methods for determining precipitations falling on the basin area, and they are all based on finding the weight coefficient for precipitation measured at a given point. By the method of arithmetic mean, summation the value of total precipitation amount taken from all analyzed stations in the Una basin area, and then division of the obtained value with the number of observation points, the average precipitation amount in the basin is $1147 \mathrm{~mm}$, see the table 1 .

On the base of Thiessen polygons and calculation from the table 2, obtained average annual precipitation amount in the Una basin sums $1177.6 \mathrm{~mm}$. The average obtained Thiessen polygon method differs for about $30 \mathrm{~mm}$ from the data obtained by the method of arithmetic meanings. 
Table 2: The annual precipitation amount in the Una Basin according to the Thiessen polygon

\begin{tabular}{|c|c|c|c|c|c|}
\hline $\begin{array}{c}\text { Area } \\
\mathbf{F} \\
\left(\mathbf{k m}^{2}\right) \\
\end{array}$ & MS & $\begin{array}{c}\text { Polygon } \\
\text { surface } \\
\text { Fn }\left(\mathbf{k m}^{2}\right)\end{array}$ & $\begin{array}{c}\text { Polygon } \\
\text { participation } F n / F\end{array}$ & $\begin{array}{c}\text { The annual } \\
\text { precipitation Pn }(\mathrm{mm})\end{array}$ & $(\mathbf{F n} / \mathbf{F}) \mathbf{P n}$ \\
\hline \multirow{19}{*}{9979,5} & Bihać & 295.2 & 0.029 & 1308 & 37.932 \\
\hline & Drvar & 486.4 & 0.049 & 1108 & 54.292 \\
\hline & $\begin{array}{l}\text { Bosanska } \\
\text { Krupa }\end{array}$ & 504.8 & 0.051 & 1192 & 60.792 \\
\hline & Cazin & 437.2 & 0.044 & 1152 & 50.688 \\
\hline & Drinić & 409.5 & 0.041 & 1331 & 54.571 \\
\hline & Kulen Vakuf & 822.6 & 0.083 & 1151 & 95.533 \\
\hline & $\begin{array}{l}\text { Bosanska } \\
\text { Kostajnica }\end{array}$ & 349.4 & 0.035 & 1004 & 35.14 \\
\hline & Bosanski Novi & 700.6 & 0.070 & 1020 & 71.4 \\
\hline & Sanski Most & 661.9 & 0.066 & 1023 & 61.518 \\
\hline & Ključ & 1184.3 & 0.118 & 1080 & 127.44 \\
\hline & Prijedor & 486.9 & 0.049 & 927 & 45.423 \\
\hline & Lušci Palanka & 735.3 & 0.074 & 1338 & 99.012 \\
\hline & $\begin{array}{l}\text { Bosanska } \\
\text { Dubica }\end{array}$ & 554.5 & 0.056 & 946 & 52.976 \\
\hline & $\begin{array}{l}\text { Bosansko } \\
\text { Grahovo }\end{array}$ & 312.5 & 0.031 & 1347 & 41.757 \\
\hline & Glamoč & 480.6 & 0.048 & 1497 & 71.856 \\
\hline & Banja Luka* & 423.4 & 0.042 & 1028 & 43.176 \\
\hline & $\begin{array}{l}\text { Mrkonjić } \\
\text { Grad* }\end{array}$ & 28.9 & 0.003 & 1075 & 3.225 \\
\hline & Gračac* & 387.6 & 0.039 & 2062 & 80.418 \\
\hline & Korenica* & 717.9 & 0.072 & 1256 & 90.432 \\
\hline \multicolumn{5}{|c|}{ Average annual precipitation quantities (mm) } & 1177.6 \\
\hline
\end{tabular}

* Meteorological monitoring outside the basin area

The isohyet method gives more accurate results than the previous ones. At this method, during the isohyet construction, their position is determined by interpolation that can and cannot be linear, what depends on conditions arouse from topographic position, distance from sea and average annual precipitation characteristics.

Table 3: The annual precipitation amount in the Una Basin by the isohyet method

\begin{tabular}{|l|l|l|l|l|}
\hline $\begin{array}{l}\text { Isohyet from - to } \\
(\mathbf{m})\end{array}$ & $\begin{array}{l}\text { The area between the two isohyet } \\
\left(\mathbf{k m}^{2}\right)\end{array}$ & $\frac{F i}{\boldsymbol{F}}$ & $\frac{\boldsymbol{P i}-\mathbf{1}+\boldsymbol{P i}}{\mathbf{2}}$ & $\frac{\boldsymbol{P i}-\mathbf{1}+\boldsymbol{P i}}{\mathbf{2}}\left(\frac{\boldsymbol{F i}}{\boldsymbol{F}}\right)$ \\
\hline $\mathbf{8 0 0}-\mathbf{9 0 0}$ & 11.9 & 0.0012 & 850 & 1.02 \\
\hline $\mathbf{9 0 0}-\mathbf{1 0 0 0}$ & 700.6 & 0.07 & 950 & 66.50 \\
\hline $\mathbf{1 0 0 0}-\mathbf{1 2 5 0}$ & 4844.2 & 0.48 & 1125 & 540.00 \\
\hline $\mathbf{1 2 5 0}-\mathbf{1 5 0 0}$ & 2999.8 & 0.3 & 1375 & 412.50 \\
\hline $\mathbf{1 5 0 0}-\mathbf{1 7 5 0}$ & 1055.7 & 0.11 & 1625 & 178.75 \\
\hline $\mathbf{1 7 5 0}-\mathbf{2 0 0 0}$ & 367.3 & 0.04 & 1875 & 75.00 \\
\hline $\mathbf{\Sigma}$ & 9979.5 & 1.00 & & 1273.77 \\
\hline
\end{tabular}


For the purpose of this paper a map was used with average annual precipitation amounts according to the SFRJ Climate Atlas.

The results of the analysis of the isohyet map, given in the table 3, show that the average annual precipitation amount in the Una basin sums $1273.8 \mathrm{~mm}$. According to these values, the annual precipitation amount is about $96 \mathrm{~mm}$ larger than the value obtained by the Thiessen polygon method, and about $125 \mathrm{~mm}$ than data obtained from the analysis by the method of arithmetic means.

Using different methods for assessing the average precipitation in the Una basin, approximately the same result is obtained in given conditions. The lowest average value is obtained by the method of arithmetic means. However, it can be concluded that precipitation increases in the Una basin area along with the altitude growth, though there are certain specifics when data obtained from individual meteorological monitoring is concerned. Dynamic relief also contributes to this, with significant morphological variety in the Una basin area, which affects forming of specific precipitation occasions and differences in pluviometric regime on local level. Precipitations decrease going from the west towards the east, but also going from the south towards the north. On the base of average trend in rising precipitation along with altitude in the Una basin of 47.7 $\mathrm{mm} / 100 \mathrm{~m}$, and by analysis of the data obtained by the isohyet method, a conclusion was reached on an average annual precipitation amount by hypsometric zones, which in average for the basin sums $1190.9 \mathrm{~mm}$.

Table 1: Total precipitation amount by hypsometric zones

\begin{tabular}{|l|l|l|l|}
\hline & Area of the zone $\left.\mathbf{( m}^{2}\right)$ & Precipitation $\left.\mathbf{( m m}-\mathbf{l} / \mathbf{m}^{2}\right)$ & Total Precipitation $\left.\mathbf{( m}^{\mathbf{3}}\right)$ \\
\hline $\mathbf{0 - 1 0 0}$ & 86830000 & 900 & 78147000 \\
\hline $\mathbf{1 0 0 - 2 0 0}$ & 1373310000 & 947.7 & 1301458887 \\
\hline $\mathbf{2 0 0 - 3 0 0}$ & 1374310000 & 995.4 & 1367988174 \\
\hline $\mathbf{3 0 0 - 4 0 0}$ & 1207630000 & 1090.8 & 1317282804 \\
\hline $\mathbf{4 0 0 - 5 0 0}$ & 781470000 & 1138.5 & 889703595 \\
\hline $\mathbf{5 0 0 - 6 0 0}$ & 633760000 & 1186.2 & 751766112 \\
\hline $\mathbf{6 0 0 - 7 0 0}$ & 785460000 & 1233.9 & 969179094 \\
\hline $\mathbf{7 0 0 - 8 0 0}$ & 749530000 & 1281.6 & 960597648 \\
\hline $\mathbf{8 0 0 - 9 0 0}$ & 674680000 & 1329.3 & 896852124 \\
\hline $\mathbf{9 0 0 - 1 0 0 0}$ & 755520000 & 1377.0 & 1040351040 \\
\hline $\mathbf{1 0 0 0 - 1 1 0 0}$ & 558900000 & 1424.7 & 796264830 \\
\hline $\mathbf{1 1 0 0 - 1 2 0 0}$ & 454110000 & 1472.4 & 668631564 \\
\hline $\mathbf{1 2 0 0 - 1 3 0 0}$ & 302410000 & 1520.1 & 459693441 \\
\hline $\mathbf{1 3 0 0 - 1 4 0 0}$ & 148710000 & 1567.8 & 233147538 \\
\hline $\mathbf{1 4 0 0 - 1 5 0 0}$ & 60880000 & 1615.5 & 98351640 \\
\hline $\mathbf{1 5 0 0 - 1 6 0 0}$ & 24950000 & 1663.2 & 41496840 \\
\hline $\mathbf{1 6 0 0 - 1 7 0 0}$ & 4990000 & 1710.9 & 8537391 \\
\hline $\mathbf{1 7 0 0}-1800$ & 2000000 & 1758.6 & 3517200 \\
\hline $\mathbf{1 8 0 0 - 1 9 0 0}$ & 1000000 & 1806.3 & 1806300 \\
\hline
\end{tabular}

The average annual precipitation sums range from $875 \mathrm{~mm}$ in the area of the Una Mouth into the Sava River, to over $1800 \mathrm{~mm}$ on the highest mountain peaks. The largest part of the basin is located within the isohyet of 900 to $1100 \mathrm{~mm}$ (valleys of the Una, Sana, basins, hills). Morpho 
structures over $500 \mathrm{~m}$ altitude have also larger precipitation amount, in average over $1200 \mathrm{~mm}$, while areas above $1000 \mathrm{~m}$ altitude receive more than $1400 \mathrm{~mm}$ annually. Knowledge on total precipitation amount by hypsometric zones has great importance and apply when analyzing total flow and inflow in the Una basin.

\subsection{Pluviometric Regime}

According to analyzed data given in the fig. 3, it comes that precipitations are equally distributed during the year. Although monthly precipitation amounts are uneven, it should be noted that during the year there are no dryness, both spatially and temporally. As it was already stated, the precipitation distribution during the year is under the influence of air fronts penetrations from the Mediterranean, Atlantic, or from the north during the winter. The basic feature that is noticed in an annual flow of the precipitation height is the existence of two extremely periods with plenty of precipitation. The first one is linked to the second part of the autumn and beginning of the winter season (October-December). During this period $324 \mathrm{~mm}$ of precipitation falls, or $108 \mathrm{~mm}$ in average by month, what is about $112 \%$ from the average annual precipitation amount. The second precipitation period is characterized with extremely reduced precipitation average, during which $82 \mathrm{~mm}$ is extracted in average, what makes $85 \%$ of average monthly value. This period of precipitation minimum binds to the second half of the winter and beginning of the spring period (January-March).

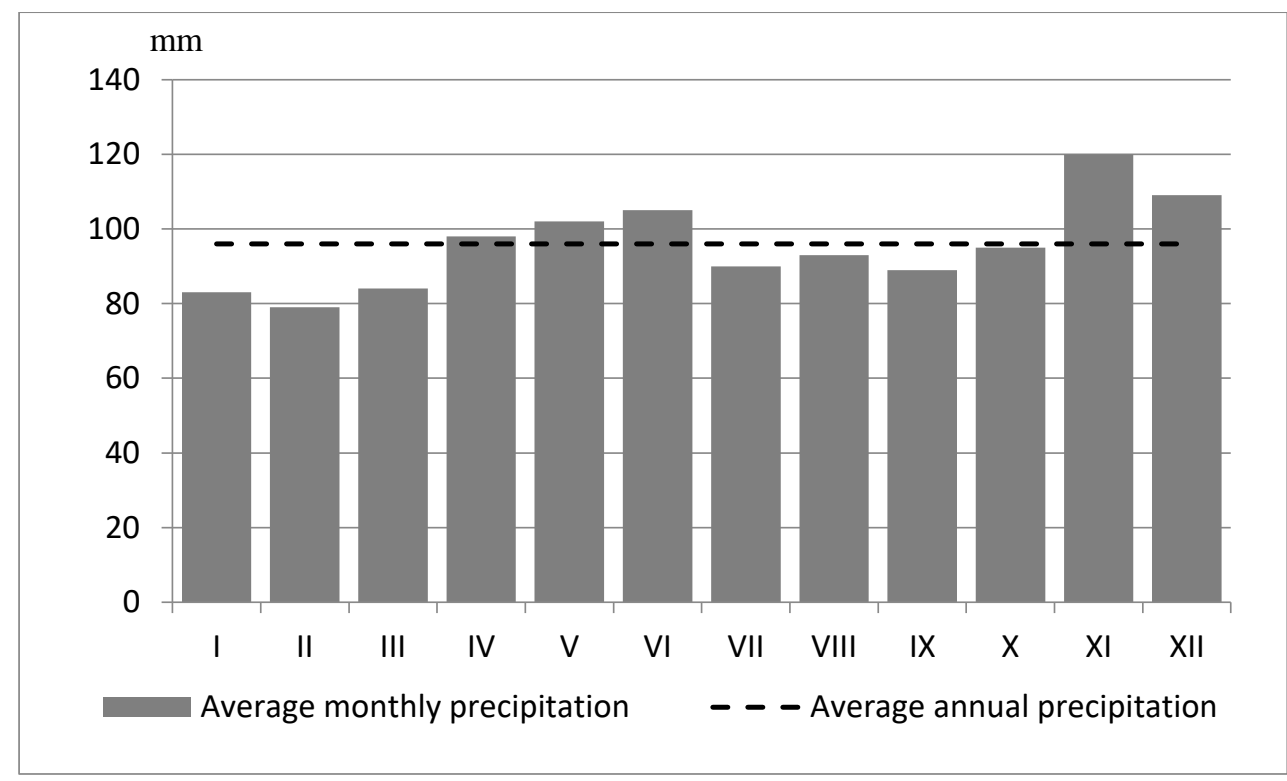

Figure 3: The graph of the average annual pluviometric regime flow

Between these characteristic precipitation periods, pluviometric regime has transitional characteristics, means that two secondary precipitation periods appear. Secondary precipitation maximum binds to the period of the second half of the spring and beginning of the summer climatic season. In this period (April-July), monthly precipitation average sums $102 \mathrm{~mm}$, what makes $106 \%$ of total monthly average. Secondary minimum corresponds to the period of the end of summer and beginning of autumn season (July-September), when in average $91 \mathrm{~mm}$ of precipitation is extracted in one month or $94 \%$. 
In general, it can be concluded that in the Una basin area, pluviometric regime is characterized with extreme two maximum, in June, and in November, and two minimum, in February, and September. Months, which show the maximum precipitations differ in individual basin's area, depends on number of factors. Maximums can appear also during May or April, while other, secondary maximum, except for November, appears also in December. Precipitation minimums as well, vary in certain parts of the Una basin. They are noticed mostly during January or March, and then also October.

Nonlinearity of the annual precipitation distribution by months is also stated by the analysis of relative annual precipitation oscillations. (Table 5).

Table 5: Relative annual precipitation oscillation in the Una basin

\begin{tabular}{|l|l|l|l|l|}
\hline Meteorological stations & Hx $(\mathbf{m m})$ & Hn $\mathbf{( m m})$ & $\mathbf{H}(\mathbf{m m})$ & $\mathbf{R}(\mathbf{\%})$ \\
\hline Bihać & 146 & 86 & 1308 & 4.59 \\
\hline Drvar & 128 & 73 & 1108 & 4.96 \\
\hline Bosanska Krupa & 120 & 73 & 1192 & 3.94 \\
\hline Bosanski Petrovac & 126 & 79 & 1149 & 4.09 \\
\hline Cazin & 129 & 76 & 1152 & 4.60 \\
\hline Drinić & 146 & 94 & 1331 & 3.91 \\
\hline Kulen Vakuf & 138 & 69 & 1151 & 5.99 \\
\hline Bosanska Kostajnica & 103 & 60 & 1004 & 4.28 \\
\hline Bosanski Novi & 104 & 66 & 1020 & 3.72 \\
\hline Sanski Most & 104 & 62 & 1023 & 4.11 \\
\hline Ključ & 116 & 69 & 1080 & 4.35 \\
\hline Prijedor & 89 & 55 & 927 & 3.67 \\
\hline Saničani & 89 & 55 & 930 & 3.66 \\
\hline Lušci Palanka & 131 & 83 & 1338 & 3.59 \\
\hline Bosanska Dubica & 106 & 58 & 946 & 5.07 \\
\hline Bosansko Grahovo & 191 & 78 & 1347 & 8.39 \\
\hline Glamoč & 206 & 74 & 1497 & 8.82 \\
\hline Una River basin & 120 & 83 & 1147 & 3.23 \\
\hline
\end{tabular}

Source: According to data of FB\&H, Sarajevo 2013.

General pluviometric relations in the Una basin is influenced, among other things, by the position of certain basin's parts and apropos, by the main climatic region's influence. On the base of this fact two pluviometric types can be distinguished: continental and maritime one, between which appear changed and transient types. Analysis of continentality of certain meteorological stations was performed by using two methods that gave different results.

The first way in determining the continentality relates to determining precipitation amount in warmer and colder period. Continental pluviometric type is characterized with larger precipitation amount that falls during warmer period of year (April-September), while for maritime type is linked maximum of precipitations during colder period (October-March) [5].

The second method in determining continentality comes down to usage of mathematical pattern, according to which, areas with continentality factor (Q) larger than 50\% have more continental pluviometric regime, and less than 50\%, more maritime one. 
As it was already stated, data on continentality of certain areas, according to used methods, differs. Bosansko Grahovo and Glamoč, are the places where maritime influences are the strongest, by the both methods. According to the method of total precipitation amount in warmer and colder period, maritime influences reach also Kulen Vakuf, Drinić, Bosanski Petrovac and Drvar, though it should be pointed out that in these places there are small differences in precipitation amounts for characteristic periods.

Table 6: Continentality factor in the Una basin

\begin{tabular}{|l|l|l|l|}
\hline Meteorological stations & IV-IX $(\mathbf{m m})$ & X-III $(\mathbf{m m})$ & $\mathbf{Q}(\boldsymbol{\%})$ \\
\hline Bihać & $\mathbf{6 6 5}$ & 643 & 58.4 \\
\hline Drvar & 543 & $\mathbf{5 6 5}$ & 56.5 \\
\hline Bosanska Krupa & $\mathbf{6 3 6}$ & 556 & 60.8 \\
\hline Bosanski Petrovac & 562 & $\mathbf{5 8 7}$ & 56.6 \\
\hline Cazin & $\mathbf{6 0 5}$ & 547 & 59.6 \\
\hline Drinić & 643 & $\mathbf{6 8 8}$ & 56.6 \\
\hline Kulen Vakuf & 547 & $\mathbf{6 0 4}$ & 54.6 \\
\hline Bosanska Kostajnica & $\mathbf{5 2 8}$ & 475 & 59.9 \\
\hline Bosanski Novi & $\mathbf{5 3 5}$ & 485 & 60.1 \\
\hline Sanski Most & $\mathbf{5 5 7}$ & 466 & 62.2 \\
\hline Ključ & $\mathbf{5 9 3}$ & 487 & 62.2 \\
\hline Prijedor & $\mathbf{5 0 1}$ & 426 & 61.4 \\
\hline Saničani & $\mathbf{4 9 9}$ & 431 & 60.9 \\
\hline Lušci Palanka & $\mathbf{7 2 3}$ & 615 & 61.4 \\
\hline Bosanska Dubica & $\mathbf{5 0 8}$ & 438 & 59.8 \\
\hline Bosansko Grahovo & 558 & $\mathbf{7 8 9}$ & $\mathbf{4 8 . 9}$ \\
\hline Glamoč & 600 & $\mathbf{8 9 7}$ & $\mathbf{4 6 . 7}$ \\
\hline Una River basin & $\mathbf{5 7 7}$ & 570 & 57.6 \\
\hline
\end{tabular}

Further analysis on annual precipitation disposition, especially on periods of maximums and minimums, led to a conclusion that Bosansko Grahovo and Glamoč have modified maritime pluviometric type $(\mathrm{Q}=45-50 \%)$, and Kulen Vakuf transitional maritime $(\mathrm{Q}=51-55 \%)$. Bosanska Dubica, Bosanska Kostajnica, Drinić, Cazin, Bosanski Petrovac, Drvar and Bihać have transitional continental pluviometric type $(\mathrm{Q}=56-60 \%)$, while extremely continental $(\mathrm{Q}>61$ \%) is represented in the area of Bosanski Novi, Bosanska Krupa, Lušci Palanka, Saničani, Prijedor, Sanski Most and Ključ. The largest monthly precipitation oscillation was registered on meteorological monitoring with the most expressive maritime influences, while the lowest one was registered in the area with extremely continental pluviometric regime.

\section{Conclusions}

Precipitations as climatic element have a special role in forming the regime of the Una River and its tributaries. Concerning the fact that water balance is the difference between inflow and evaporation, from that it results that precipitations do not have only special role but they are also the most important factor in the river regime. The spatial coverage of the Una basin, concerning its position and size, gets different amounts of precipitation. Precipitations decrease going from the west towards the east, but also going from the south towards the north. Increase of annual precipitation amounts is noticed along with increase of the station's altitude, which, however is 
not continuous and there are exceptions as well. The reason for this fact comes from the positions of individual meteorological monitoring, characteristics of relief, but also atmospheric processes. The analysis found that annual precipitation amount in the basin increases by $47.7 \mathrm{~mm}$ per every $100 \mathrm{~m}$. The results of applying different methods for the evaluation of average precipitations in the Una basin show that in given conditions approximate result is obtained, regardless on applied method. The lowest average value is obtained using the method of arithmetic meanings, $1147 \mathrm{~mm}$. The results of the analysis of the isohyet chart show that the largest value of average annual precipitation amount in the Una basin is obtained by this method and it sums $1273.8 \mathrm{~mm}$. That is for about $96 \mathrm{~mm}$ larger value than the one obtained by the Thiessen polygon method $(1177.6 \mathrm{~mm})$. Average value of the total precipitation amount using vertical gradient of precipitations by hypsometric zones sums $1190.9 \mathrm{~mm}$. All these differences are product of different physical-geographical position of stations for monitoring as well as absence of continuous monitoring in all hypsometric zones in the basin area.

It can be concluded that in the Una basin area, pluviometric regime is characterized by two extreme maximums, in June and November, and two minimums, in February and in September. However, months with precipitation maximums differ by individual meteorological stations, depending on a number of factors. Thus, maximums can appear also during May or April. Second or secondary maximum appears not only in November, but also in December. Minimums as well, vary by individual stations. They are noticed mainly during January or March and then also in October. Generally looking the Una basin, it is concluded that this area belongs to continental, and that extremely and transitional continental pluviometric regime.

\section{References}

[1] Drešković, N. Climate types in Bosnia and Herzegovina, doctoral dissertations, Sarajevo: Faculty of Science, Department of Geography, University of Sarajevo. 2011, 16.

[2] Ducić, V., Anđelković, G. Climatology, Practicum for geographers, Beograd: University of Beograd, Faculty of Geography. 2004,

[3] Dukić, D. Hydrology of land, Beograd: Scientific book. 1984, 178.

[4] Hrelja, H. Engineering hydrology, Sarajevo: Faculty of Civil Engineering, University of Sarajevo, 2007, 140-144.

[5] Spahić, M. The River Una, potamological considerations, Bulletin of ecology society of Bosnia and Herzegovina, Series B, No. 6, 1991, 11-20.

[6] Spahić, M., Korjenić, A., Hrelja E. Problems of genesis, evolution and protection of the Una tuff in Una National park, Eco.mont, Vol. 6, No. 2, Wien: Austrian Academy of Sciences Press, 2014, 47-53.

[7] Groundwater bodies on the territory of the Federation of Bosnia and Herzegovina, Vol. 1, Institute for Water Management, Sarajevo, 2009.

[8] Vemić, M. About a new criterion for the assessment of the continentality of the pluviometric regime and the continentality of the area, Geographical Overview III, Sarajevo: Geographical Society of the Bosnia and Herzegovina, 1959, 5-26.

[9] WMO, Guide to Hydrometeorological Practices, No. 168, Geneva, 1970, 8.

[10] Žigić I., Skopljak F., Hrvatović H., Pašić-Škripić D. Hydrogeological reionization of the terrain in the Una River Basin on the territory of the Federation of Bosnia and Herzegovina, Proceedings book, Tuzla: Faculty of Mining and Geology, University of Tuzla. 2010.

*Corresponding author.

E-mail address: aida.k@ pmf.unsa.ba 